\title{
Ethnic differences in risk markers for heart disease in Bradford and implications for preventive strategies
}

\author{
T Knight, Z Smith, J A Lockton, P Sahota, A Bedford, M Toop, E Kernohan, M R Baker
}

\begin{abstract}
Objectives-To assess and compare the prevalence of established risk markers for ischaemic heart disease in a sample of Asian and non-Asian men and to relate these observations to preventive strategies.
\end{abstract}

Setting-Two factories in the textile industry in Bradford, West Yorkshire, UK.

Subjects-288 male manual workers aged 20 to 65 years.

Design-Cross sectional study within one occupational/social class stratum.

Measurements and main results-Age, body mass index, plasma lipids, fibrinogen and serum insulin values, blood pressure, smoking habits, alcohol consumption, and exercise routines were recorded. Plasma total cholesterol concentrations were significantly lower in Asian than non-Asian men (5.3 $\mathrm{mmol} / \mathrm{l} v 5.8 \mathrm{mmol} / \mathrm{l}$ respectively, $\mathrm{p}<0.0001)$, as were low density lipoprotein cholesterol concentrations $(3.4 \mathrm{mmol} / 1$ v $3.7 \mathrm{mmol} / 1$, $\mathbf{p}=0.0150)$, and high density lipoprotein (HDL) cholesterol $(1 \cdot 1 \mathrm{mmol} / \mathrm{l} \quad v \quad 1 \cdot 3$ mmol/1, p<0.0001). Hypercholesterolaemia (concentration $>6.5 \mathrm{mM}$ ) was present in nearly one quarter of non-Asians but less than one eighth of Asian men. Triglyceride values were not significantly higher in Asians. Smoking rates were high in nonAsians (43.8\%) and only slightly lower in Asians (39-1\%). Asian smokers smoked fewer cigarettes per day on average $(9.3 v 16 \cdot 1$, $\mathbf{p}=\mathbf{0 . 0 0 0 1 )}$. Almost a quarter of non-Asian men (23.1\%) and $26.6 \%$ of Asian men had raised blood pressure. Systolic pressures were higher in non-Asian men $(138.3 \mathrm{mmHg}$ $v 133.0 \mathrm{mmHg}, p=0 \cdot 0070$ ), but diastolic pressures showed no ethnic differences. Diabetes was more prevalent in Asian men $(10.9 \%$ v $4.4 \%$ p $<0.05)$, who also showed higher serum insulin concentrations after glucose loading $(22.3 \mathrm{mU} / 1$ v $10.2 \mathrm{mU} / 1$, $\mathbf{p}<0.0001)$. Plasma fibrinogen values were higher in non-Asian men $(2.9 \mathrm{~g} / \mathrm{l} v 2.6 \mathrm{~g} / \mathrm{l}$, $\mathbf{p}<0.0001)$ and these were associated with smoking. Nearly all non-Asians (92.5\%) consumed alcohol at some time whereas $62 \cdot 5 \%$ of Asians habitually abstained from alcohol consumption. Among the drinkers, nonAsian men consumed on average, 23.9 units per week and Asian men 18.4 units per week $(p=0 \cdot 083)$. The mean body mass index for Asian men was $24.5 \mathrm{~kg} / \mathrm{m}^{2}$ which was not significantly different to the mean in nonAsian men $\left(25 \cdot 2 \mathrm{~kg} / \mathrm{m}^{2}\right)$. The frequency of exercise in leisure time was low in both groups with $44 \cdot 4 \%$ of non-Asian and $21 \cdot 1 \%$ of
Asian men taking moderate exercise weekly, and even fewer, regular strenuous exercise ( $16.3 \%$ and $8 \cdot 6 \%$ respectively).

Conclusions-The plasma cholesterol and fibrinogen concentrations, prevalence of hypertension, smoking habits, alcohol intakes, and infrequency of exercise in leisure time in these non-Asian men in Bradford were consistent with an increased risk of heart disease. The pattern of risk markers was clearly different in Asian men. Only their lower HDL cholesterol concentrations, marginally higher triglyceride values, higher prevalence of diabetes, and very low frequency of exercise in leisure time would be consistent with a higher risk of heart disease compared with non-Asians. The implications of these observations for heart disease preventive strategies are discussed.

f Epidemiol Community Health 1993; 47: 89-95

Heart disease prevention strategies in the UK are based on over two decades of research and few would dispute that their main targets, raised serum cholesterol concentrations, blood pressure, and smoking are major markers of risk of ischaemic heart disease. ${ }^{1}$ Doubts may arise, however, in the application of these strategies to populations which differ in terms of race and culture from those from which the bulk of the data were collected-that is white, western, middle aged men and, to a lesser extent, women.

Asian immigrant communities in the UK have attracted interest because of their high risk of ischaemic heart disease, ${ }^{2}{ }^{4}$ and in an extensive review, McKeigue concluded that these high rates seemed to be common in all South Asian immigrant communities living overseas. ${ }^{5}$ The high rates of ischaemic heart disease observed, however, cannot be explained by high serum cholesterol concentrations, smoking, or hypertension. $^{5}$

These observations have important implications for ischaemic heart disease prevention in the UK suggesting that the 'traditional' approach may not be sufficiently sensitive for Asian communities. Furthermore, Asian communities in the UK vary in terms of their cultural origins, and thus the prevention strategies suggested by studies of some communities may not be suitable for others.

Bradford, West Yorkshire has the second worst standardised mortality ratio (SMR) (for men) for ischaemic heart disease of all district health 
authorities in England (the SMR for 1988 was 132). ${ }^{67}$ The city was also a major destination for Asian immigrants in the 1950 s and 60 s, and at the last census, $15 \%$ of the population were classified as 'of Asian origin', with some two thirds from Pakistan.'

This paper describes a study conducted in Bradford which aimed to assess and compare the prevalence and levels of a wide range of risk markers for ischaemic heart disease in a sample of male residents of Asian and non-Asian origin. The implications the results have for ischaemic heart disease preventive strategies are discussed.

\section{Methods}

The protocol for this study was approved by the district ethical committee and written consent was obtained from all subjects.

\section{SUBJECTS}

The subjects were male, manual workers of Asian and non-Asian origin (defined by name and stated origin).

\section{SETTING}

The study was conducted within two factories in the traditional textile industry in Bradford. Both had a substantial proportion of Asian men in the workforce and the nature of the work was comparable, both between and within factories. Only departments where men from both ethnic groups worked together on the same tasks were included in the study.

\section{PROCEDURE}

'Lifestyle' questionnaires (general demographic information, medical history, smoking, exercise and alcohol consumption habits) and diet diaries were completed, and these were checked through at interview with all subjects (translations into Asian languages were available (PS)). Blood samples were taken during an early morning appointment, and blood pressures and height and weight were measured during an afternoon session.

\section{BLOOD SAMPLES}

Fasted blood samples were taken into bottles containing EDTA for lipid determinations. Total plasma cholesterol was measured enzymatically by the method of Allain et $a l^{8}$ modified for the IL Monarch Centrifugal Analyser. Kits were supplied by Instrumentation Laboratory (UK) Ltd. Calibration was against a secondary standard supplied by Coulter Electronics Ltd, Luton. The intra-assay precision $(\% \mathrm{CV})$ was $1.43 \%$ at a concentration of $6.23 \mathrm{mM}$ and the inter-assay value was $2.03 \%$ at a concentration of $6.25 \mathrm{mM}$. High density liproprotein cholesterol (HDL cholestrol) was measured by the polyethylene glycol precipitation method of Gidez et al, ${ }^{9}$ followed by cholesterol measurement (as above). Calibration was against a secondary standard (Coulter Electronics Ltd). The intra-assay precision was $1.48 \%$ at a concentration of $1.23 \mathrm{mM}$ and the inter-assay precision was $4 \cdot 3 \%$ at the same concentration. The secondary standards described above were validated against the Centres for Disease Control (CDC) human serum pools released through CDC and National Heart and Lung Institute (NHLI) lipid standardisation programs. The low density lipoprotein cholesterol (LDL cholesterol) concentration was calculated using the Friedwald formula. ${ }^{10}$

Triglycerides were assayed on an IL Monarch Centrifugal Analyser using a commercially available kit (Instrumentation Laboratories UK Ltd) based on the method of Bucolo and David. ${ }^{11}$ The assay was standardised by calculating triglyceride as Triolein equivalent based on the molar absorption coefficient of NADH. The intra-assay precision was $2 \cdot 20 \%$ at a concentration of $2 \cdot 65 \mathrm{mM}$ and inter-assay precision, $2.63 \%$ at a concentration of $2.63 \mathrm{mM}$.

Blood samples for plasma glucose and serum insulin analyses were taken two hours after ingestion of an oral dose of $75 \mathrm{~g}$ glucose (taken in $330 \mathrm{ml}$ Lucozade). Subjects fasted over the two hour period. Plasma glucose was assayed along with routine NHS specimens (in the Clinical Biochemistry Department, Bradford Royal Infirmary) using a specific enzymatic method. Samples were assayed on the same day as collection and batch precision data are therefore not available. Serum insulin concentrations were measured using a commercially available Radioimmunoassay kit (Pharmacia UK). The within assay precision was below $10 \%$ over the range of concentrations measured, and in an external quality control scheme (Department of Biochemistry, The Guildford Hospital) our assay results were consistently within the cluster of values reported by participating laboratories.

Fibrinogen concentrations were determined in fasted citrated plasma using a Boehringer Haemodiagnostic test, a method based on the Clauss technique which uses the thrombin clotting time as a basis for fibrinogen calculation. Samples were analysed on the day of collection along with routine NHS specimens in the Department of Haematology, Bradford Royal Infirmary.

\section{BLOOD PRESSURES}

Blood pressures were measured using an electronic sphygmomanometer (Copal) after at least 15 minutes' rest. All measurements were made by one observer only.

\section{STATISTICAL ANALYSES}

Questionnaire and clinical data were analysed using the SPSSX software program. Data for plasma triglyceride and serum insulin concentrations were normalised by logarithmic transformation and means are therefore geometric. Parametric statistical tests were applied using two tailed $\mathrm{p}$ values throughout.

\section{Results}

\section{RESPONSE RATES}

The response rate was similar in both factories$73.7 \%$ in factory A and $76.2 \%$ in factory B (mean $75.0 \%)$. The response was higher in the Asian men; $83.4 \% v 70.6 \%(\mathrm{p}<0.002)$. A total of 315 men (175 non-Asian and 140 Asian) started the study but 27 were subsequently lost-four men went on long term sick leave, three left the employ of the factory, and nine could not fully meet study commitments because of shift patterns, thus there 
were 11 true withdrawls $(3 \cdot 4 \%)$. Data are therefore presented for 288 men (160 Europeans and 128 Asians), $91 \cdot 4 \%$ of the original sample.

AGE

The mean age was the same for both ethnic groups, 41 years, with a range of $20-65$ years among non-Asian men and 20-62 years in Asian men. The age distribution of the sample is given in table I.

BODY MASS INDEX

The mean body mass index (BMI) for the nonAsian men was $25.2 \mathrm{~kg} / \mathrm{m}^{2}$ (95\% confidence interval (CI): $24 \cdot 7,25 \cdot 7$ ) and for the Asian men

Table I Distribution of subjects by age and body mass index (BMI)

\begin{tabular}{llr}
\hline & $\begin{array}{l}\text { Non-Asian } \\
\text { No }(\%)\end{array}$ & $\begin{array}{l}\text { Asian } \\
\text { No }(\%)\end{array}$ \\
\hline Age group (y): & & \\
$20-29$ & $30(18 \cdot 8)$ & $14(10 \cdot 9)$ \\
$30-39$ & $37(23 \cdot 1)$ & $55(43 \cdot 0)$ \\
$40-49$ & $52(32 \cdot 5)$ & $29(22 \cdot 7)$ \\
$50+$ & $41(25 \cdot 6)$ & $30(23 \cdot 4)$ \\
BMI $\left(\mathrm{kg} / \mathrm{m}^{2}\right):$ & $83(51 \cdot 9)$ & $74(57 \cdot 8)$ \\
$<25 \cdot 0$ & $64(40 \cdot 0)$ & $49(38 \cdot 3)$ \\
$25 \cdot 1-29 \cdot 9$ & $13(8 \cdot 1)$ & $5(3 \cdot 9)$ \\
$>30 \cdot 0$ & & \\
\hline
\end{tabular}

Table II Blood lipids, insulin, and fibrinogen values and blood pressure in Asian and non-Asian men in Bradford.

\begin{tabular}{|c|c|c|c|}
\hline & $\begin{array}{l}\text { Non-Asian } \\
(n=160)\end{array}$ & $\begin{array}{l}\text { Asian } \\
(n=128)\end{array}$ & $p$ value* \\
\hline Cholesterol $(\mathrm{mmol} / \mathrm{l})$ (mean $(95 \% \mathrm{CI})$ ): & $5 \cdot 8$ & $5 \cdot 3$ & $\mathrm{p}<0 \cdot 0001$ \\
\hline LDL & $\begin{array}{l}(5 \cdot 6,6 \cdot 0) \\
3 \cdot 7 \\
(3 \cdot 6,3 \cdot 9)\end{array}$ & $\begin{array}{l}(5 \cdot 1,5 \cdot 3) \\
3 \cdot 4 \\
(3 \cdot 3,3 \cdot 6)\end{array}$ & $\mathrm{p}=0.0150$ \\
\hline HDL & & $\begin{array}{c}1 \cdot 1 \\
(1 \cdot 1,1 \cdot 2)\end{array}$ & $\mathrm{p}<0.0001$ \\
\hline Triglycerides & $\begin{array}{c}1 \cdot 3 \\
(1 \cdot 2,1 \cdot 4)\end{array}$ & $\begin{array}{c}1 \cdot 4 \\
(1 \cdot 3,1 \cdot 5)\end{array}$ & $p=0 \cdot 129$ \\
\hline $\begin{array}{l}\text { Serum insulin in normoglycaemic men } \\
(\mathrm{mU} / \mathrm{l})(\text { mean }(95 / \% \mathrm{CI}))\end{array}$ & $\begin{array}{l}\mathrm{n}=148 \\
10 \cdot 2 \\
(9 \cdot 1,11 \cdot 5)\end{array}$ & $\begin{array}{l}\mathrm{n}=96 \\
22 \cdot 3 \\
(19 \cdot 3,25 \cdot 8)\end{array}$ & $\mathrm{p}<0.0001$ \\
\hline $\begin{array}{l}\text { Plasma fibrinogen } \\
(\mathrm{g} / \mathrm{l})(\text { mean }(95 \% \mathrm{CI})) \dagger\end{array}$ & $\begin{array}{c}\mathrm{n}=148 \\
2 \cdot 9 \\
(2 \cdot 8,3 \cdot 0)\end{array}$ & $\begin{array}{l}\mathrm{n}=108 \\
2 \cdot 6 \\
(2 \cdot 5,2 \cdot 8)\end{array}$ & $\mathrm{p}<0.0001$ \\
\hline \multicolumn{4}{|l|}{ Blood pressure: } \\
\hline $\begin{array}{l}\text { Raised blood pressure (\% (no)) } \\
\text { Systolic (mmHg) (mean }(95 \% \mathrm{CI}))\end{array}$ & $\begin{array}{l}23 \cdot 1(37) \\
138 \cdot 3 \\
(135 \cdot 8,140 \cdot 8)\end{array}$ & $\begin{array}{l}26 \cdot 6(34) \\
133 \cdot 0 \\
(130 \cdot 2,135 \cdot 9)\end{array}$ & $\begin{array}{l}\mathrm{p}=0.05 \ddagger \\
\mathrm{p}=0.0070\end{array}$ \\
\hline Diastolic $(\mathrm{mmHg})($ mean $(95 \% \mathrm{CI})) \S$ & $\begin{array}{l}80 \cdot 1 \\
(78 \cdot 7,81 \cdot 7)\end{array}$ & $\begin{array}{l}80 \cdot 8 \\
(79 \cdot 0,82 \cdot 6)\end{array}$ & $\mathrm{p}=0.5690$ \\
\hline
\end{tabular}

* Significance of $\mathrm{F}$ from analysis of variance between two groups with age (years) and BMI as covariates.

†Blood samples for fibrinogen determinations were not obtained from all subjects.

$\ddagger$ Significance of difference between two proportions.

\$Excluding 10 men (4 non-Asian and 6 Asian) with previously diagnosed and treated hypertension.

Table III Smoking habits in Asian and non-Asian men and the association between smoking and fibrinogen

\begin{tabular}{|c|c|c|c|}
\hline & $\begin{array}{l}\text { Non-Asian } \\
(n=160)\end{array}$ & $\begin{array}{l}\text { Asian } \\
(n=128)\end{array}$ & $p$ value ${ }^{*}$ \\
\hline $\begin{array}{l}\text { Never Smoked (\% (no)) } \\
\text { Current Smokers (\% (no)) } \\
\text { Age (y) (\% (no)): }\end{array}$ & $\begin{array}{l}30 \cdot 0(48) \\
43 \cdot 8(70)\end{array}$ & $\begin{array}{l}48 \cdot 4(62) \\
39 \cdot 1(50)\end{array}$ & $\begin{array}{l}\mathrm{p}<0.01 \\
\mathrm{p}<0.05\end{array}$ \\
\hline $\begin{array}{l}20-29 \\
30-39 \\
40-49 \\
50+ \\
\chi^{2}(\mathrm{df}=3) \dagger \\
\mathrm{p} \text { value }\end{array}$ & $\begin{array}{l}26 \cdot 7 \quad(8) \\
43 \cdot 2(16) \\
48 \cdot 1(25) \\
51 \cdot 2(21) \\
7 \cdot 81 \\
\mathrm{p}>0 \cdot 05\end{array}$ & $\begin{array}{l}42.9(6) \\
30.9(17) \\
41 \cdot 4(12) \\
39 \cdot 1(50) \\
4 \cdot 38 \\
\mathrm{p}>0.05\end{array}$ & \\
\hline $\begin{array}{l}20-29 \text { years } \\
30+\text { years } \\
\text { p value }\end{array}$ & $\begin{array}{l}26 \cdot 7 \% \\
47 \cdot 7 \% \\
p=0 \cdot 037\end{array}$ & $\begin{array}{l}42 \cdot 9 \% \\
38 \cdot 6 \% \\
p>0 \cdot 05\end{array}$ & \\
\hline $\begin{array}{l}\text { Cigarettes/day } \\
\text { (mean }(95 \% \mathrm{CI}) \text { ) } \\
\text { Plasma fibrinogen mean (no): } \S\end{array}$ & $\begin{array}{l}16 \cdot 1 \\
(14 \cdot 0,18 \cdot 3)\end{array}$ & $\begin{array}{l}9 \cdot 3 \\
(6 \cdot 7,11 \cdot 8)\end{array}$ & $\mathrm{p}=0.0001 \ddagger$ \\
\hline $\begin{array}{l}\text { None } \\
1-10 \\
11-20 \\
>20\end{array}$ & $\begin{array}{l}2 \cdot 8(81) \\
3 \cdot 0(21) \\
3 \cdot 3(31) \\
3 \cdot 2(15) \\
\mathrm{t}=2 \cdot 937 \\
\mathrm{p}=0.004\end{array}$ & $\begin{array}{l}2 \cdot 6(66) \\
2 \cdot 8(29) \\
2 \cdot 6(10) \\
2 \cdot 7(3) \\
\mathrm{t}=0 \cdot 507 \\
\mathrm{p}>0.05\end{array}$ & \\
\hline
\end{tabular}

* Significance of difference between two proportions.

tSignificance of $\chi^{2}$ test for smoking in the four age groups.

$\ddagger$ Significance of $F$ from analysis of variance between two groups.

$\oint$ Linear regression; plasma fibrinogen levels by number of cigarettes smoked per day. was $24 \cdot 5 \mathrm{~kg} / \mathrm{m}^{2}$ (95\% CI: $\left.24 \cdot 0,25 \cdot 1\right)$. The means were not significantly different $(\mathrm{p}=0.0939)$. Three categories of BMI have been used; $<25.0$ (not overweight), 25.1-29.9 (overweight), 30.0+ (obese). The proportion of men classified as overweight or obese was higher in non-Asian men (table I).

\section{PLASMA LIPIDS}

Data for plasma total, HDL, and LDL cholesterol concentrations are presented in table II for both ethnic groups. Asian participants had significantly lower mean concentrations of all cholesterol fractions, than non-Asian participants $(\mathrm{p}<0.0001$, $\mathrm{p}<0.0150$, and $\mathrm{p}<0.0001$ respectively). Triglyceride values were higher in Asians but the difference did not reach significance.

The trends in cholesterol and triglyceride concentrations with increasing age and BMI are illustrated in the figure. Total and LDL cholesterol values increased significantly with age in both non-Asian (both $\mathrm{p}<0.0001)$ and Asian $(\mathrm{p}=0.0168$ and $p=0.0190$ ) men. After an initial sharp rise, concentrations seemed to plateau in both groups, although the changes appeared to occur at an earlier age in the Asian men. For HDL cholesterol, the trend was in the reverse direction, although this was significant only for non-Asian men $(p=0.0058)$. HDL cholesterol concentrations were lower in Asian men at all ages. The plasma triglyceride concentration increased steadily with increasing age in both ethnic groups but the trend was significant only for non-Asian men $(\mathrm{p}=0 \cdot 0012)$.

Significant increases in total and LDL cholesterol with increasing BMI were found in nonAsian men only $(p=0.0157$ and $p=0.0235$ respectively). The clear (age adjusted) rise in triglyceride values with increasing BMI was, however, significant for both ethnic groups $(p=0.0026$ for non-Asian men and $p=0.001$ for Asian men). HDL cholesterol values decreased significantly with increasing $\mathrm{BMI}$ in both non-Asian and Asian groups $(p=0.0208, p=0.0012$ respectively).

DIABETES

Subjects were classified as diabetic if they had previously been diagnosed as such or if they were found to have a plasma glucose concentration of $11.0 \mathrm{mM}$ or above two hours after a $75 \mathrm{~g}$ oral glucose load. Using these criteria, seven nonAsian and 14 Asian men were classified as diabetic. Thus, the prevalence of diabetes was $10.9 \%$ among Asian men $v 4.4 \%$ among non-Asian men, an almost threefold difference $(p<0 \cdot 05)$. Among men with normal glucose values, the mean serum insulin concentration two hours after glucose load in the Asians was more than double that in non-Asians $(22.3 \mathrm{mU} / 1$ v $10.2 \mathrm{mU} / \mathrm{l}, \mathrm{p}<0.0001)$ (table II).

FIBRINOGEN

Plasma fibrinogen values were significantly higher in the non-Asian men $(2.9 v 2.6 \mathrm{~g} / \mathrm{l}, \mathrm{p}<0.0001)$, when adjusted for age, body mass index, and smoking (table II). A significant association was found between fibrinogen values and smoking within the non-Asian group only (table III). 
BLOOD PRESSURE

For the purpose of this study, a systolic blood pressure of $160 \mathrm{mmHg}$ or more or a diastolic pressure of $90 \mathrm{mmHg}$ or more was considered 'raised'. Using these criteria, 33 (20.6\%) nonAsian men and $28(21.9 \%)$ Asian men were found to have raised blood pressure. A further four non-Asian and six Asian men had already been diagnosed as hypertensive by their own general practitioner. The blood pressures of these 10 men were excluded from the mean blood pressures given in table II. Non-Asian men had a significantly higher mean systolic blood pressure than Asian men $(p=0.007)$. Mean diastolic pressures, however, were similar in both groups.
SMOKING

A (non-significantly) higher proportion of nonAsians were current smokers compared with Asian men $(43.8 \% \quad v 39.1 \%)$, whereas more Asians had never smoked $(48.4 \%$ v $30 \cdot 0 \%$ $\mathrm{p}<0.01$ ) (table III). In non-Asian men the proportion of smokers increased with age, although only a comparison between the youngest age group (20-29 years, $26 \cdot 7 \%$ smokers) and the older men $(30+$ years $47 \cdot 7 \%)$ was significant $(p=0.037)$. In the Asian group, smoking rates showed no significant trend with age. Among the current smokers, the number of cigarettes smoked per day was significantly higher in non-Asian men $(16 \cdot 1 v 9 \cdot 3, \mathrm{p}=0.0001)$.

Total cholesterol
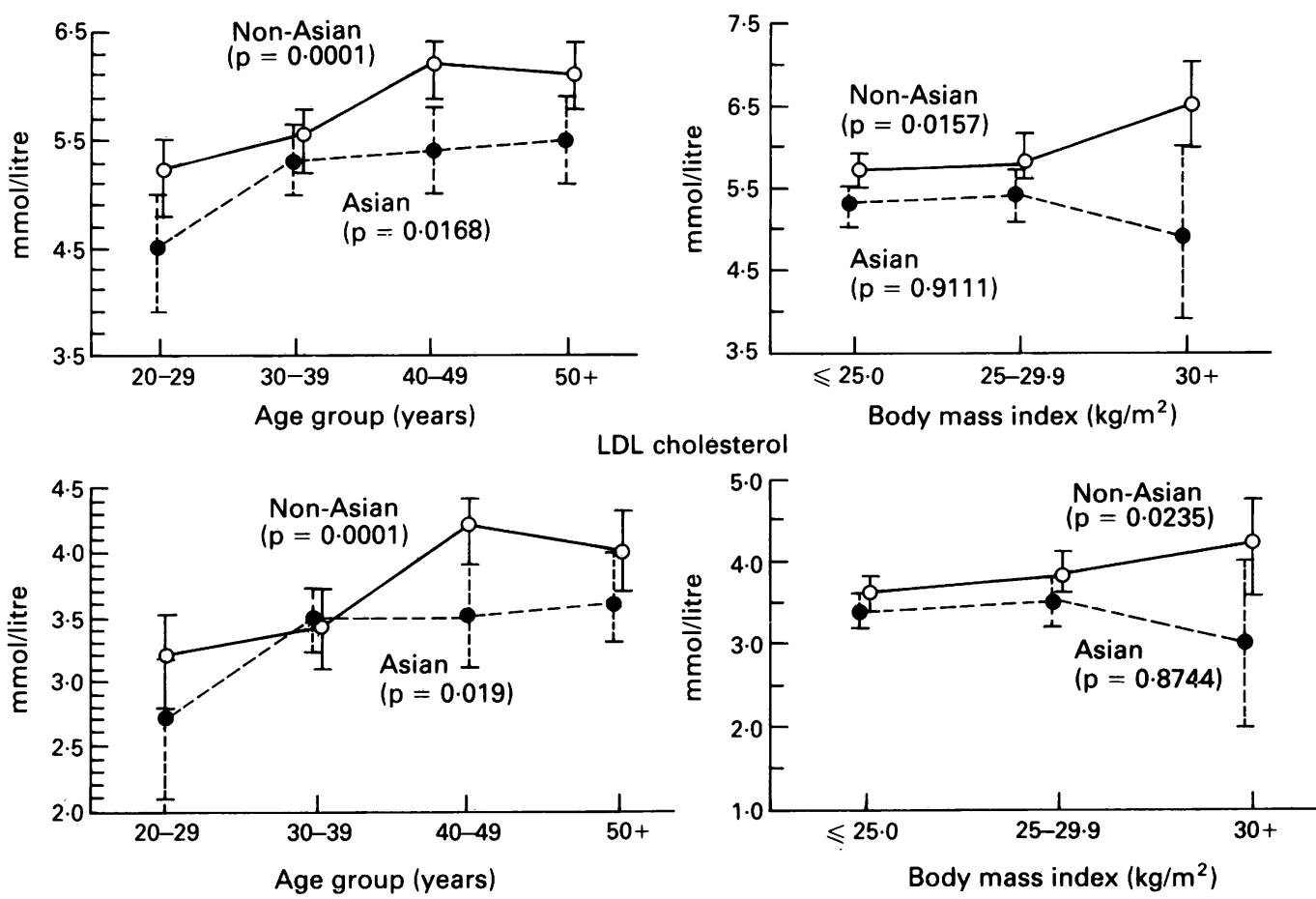

cholesterol

Plasma lipid concentrations by age group and body mass index category. $p$ value-significance of linear regression, plasma lipid value on age (years) or body mass index (adjusted for either age or body mass index).
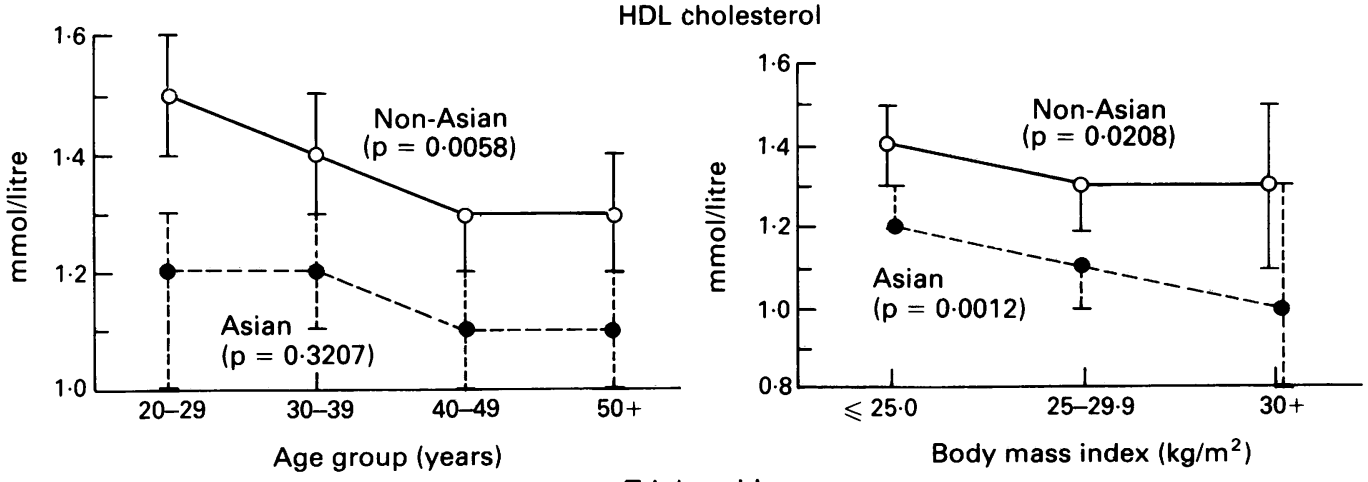

Triglycerides
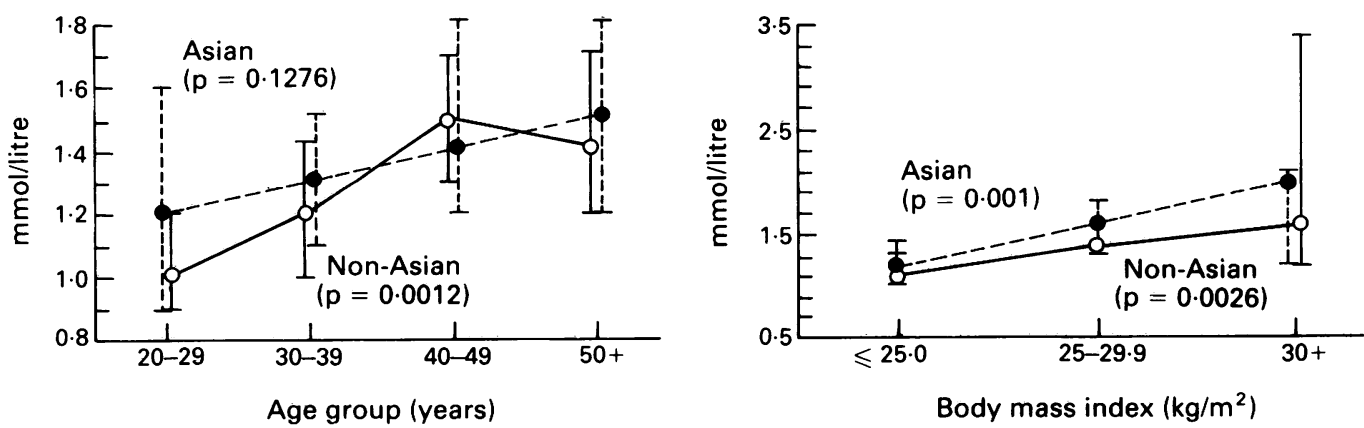
Table IV Reported habitual alcohol consumption in non-Asian and Asian men

\begin{tabular}{|c|c|c|c|}
\hline & $\begin{array}{l}\text { Abstainers } \\
\text { No }(\%)\end{array}$ & $\begin{array}{l}\text { Drinkers } \\
\text { No (\%) }\end{array}$ & $\begin{array}{l}\text { Units/week* } \\
\text { Mean }(95 \% \text { CI) }\end{array}$ \\
\hline $\begin{array}{l}\text { Non-Asian } \\
\text { Asian } \\
\text { p value }\end{array}$ & $\begin{array}{l}12(7 \cdot 5) \\
80(62 \cdot 5) \\
\mathrm{p}<0 \cdot 0001 \dagger\end{array}$ & $\begin{array}{r}148(92.5) \\
48(37.5) \\
\mathrm{p}<0.0001 \dagger\end{array}$ & $\begin{array}{l}23 \cdot 9(20 \cdot 8,27 \cdot 0) \\
18 \cdot 4(13 \cdot 0,23 \cdot 8) \\
p=0 \cdot 0830 \ddagger\end{array}$ \\
\hline
\end{tabular}

ALCOHOL CONSUMPTION

Nearly two thirds of Asian men $(93.8 \%$ of whom were Muslim) habitually abstained from alcohol consumption (table IV). Most non-Asian men $(92.5 \%)$ reported regular alcohol intake at the time of the study. The mean level of consumption (standard units per week) in drinkers was higher but not significantly so in non-Asian men (23.9 $v$ $18.4 \mathrm{p}=0 \cdot 0830$ ).

\section{EXERCISE IN LEISURE TIME}

At all levels, fewer Asians than non-Asians took regular physical activity during leisure time-the difference between proportions was significant for light $(p<0.01)$ and moderate $(p<0.0001)$ exercise. Even among non-Asians, over a quarter $(28 \cdot 1 \%)$ of the men did not regularly perform even a low level of physical activity and only $16.2 \%$ recorded regular strenuous activities (table V).

\section{Discussion}

Plasma total cholesterol concentrations recorded here for non-Asian men over 40 years of age were comparable with those from the British Regional Heart Study ${ }^{12}$ for residents of Wigan and Merthyr Tydfil, populations with SMRs for ischaemic heart disease similar to that in Bradford. In Bradford, $23.8 \%$ of non-Asian men had serum cholesterol concentrations over $6.5 \mathrm{mM}$, the value at which the European Atherosclerosis Society recommends the issue of dietary advice, and $3.8 \%$ had concentrations over $7 \cdot 8 \mathrm{mM}$, for which active treatment is recommended. ${ }^{13}$ Very similar results were reported by Mann et al ${ }^{14}$ for male residents of Glasgow aged 25-29 years. Our observations are therefore consistent with the long standing high risk of heart disease among men in Bradford.

In contrast, Asian men had lower concentrations of both total and LDL cholesterol, and only $11.7 \%$ had total values above $6.5 \mathrm{mM}$ and $1.6 \%$ above $7.8 \mathrm{mM}$. Five other British studies have reported similar and lower levels in Asians compared with their non-Asian counterparts. ${ }^{15-19}$ These observations therefore seem at odds with the recorded higher risk of ischaemic heart disease in UK Asians. ${ }^{2-5}$ Consistent with a higher risk, however, several of these studies reported lower

Table V Number (\%) of men who do not take regular physical activity ${ }^{*}$ during leisure time.

\begin{tabular}{llcl}
\hline & $\begin{array}{l}\text { Light exercisse } \\
\text { No }(\%)\end{array}$ & $\begin{array}{l}\text { Moderate exercise } \\
\text { No }(\%)\end{array}$ & $\begin{array}{l}\text { Strenuous exercise } \\
\text { No }(\%)\end{array}$ \\
\hline Non-Asian & $45(28 \cdot 1)$ & $89(55 \cdot 6)$ & $134(83 \cdot 8)$ \\
Asian & $55(43 \cdot 0)$ & $101(78 \cdot 9)$ & $117(91 \cdot 4)$ \\
p value & $\mathrm{p}<0 \cdot 01$ & $\mathrm{p}<0 \cdot 0001$ & $\mathrm{p}>0 \cdot 05$ \\
\hline${ }^{\star}$ Definitions were based on the list included in the Health Education & Authority Look after your \\
heart booklet. Lists were provided in the questionnaire. &
\end{tabular}

heart booklet. Lists were provided in the questionnaire.
HDL cholesterol and higher triglyceride concentrations in Asians. ${ }^{16-19}$ Bradford Asians had significantly lower HDL cholesterol values and although triglyceride concentrations were not found to be significantly different between ethnic groups, mean values were higher in the Asian men overall, and for all BMI and all but one age group.

Not only did we find ethnic differences in mean lipid concentrations, but there were also differences in the age and BMI trends. HDL cholesterol values decreased and triglyceride values increased significantly with age in non-Asian men only. Total and LDL cholesterol concentrations increased with age in both groups but the sharpest increase occurred at an earlier age in the Asian men. If these observations reflect true physiological age effects, then the aetiological factors (whether the same in both ethnic groups or not) seem to exert their influence earlier in Asians. In a study of coronary artery disease in Birmingham, ${ }^{20}$ Asians had more severe disease than age matched non-Asians, suggesting earlier onset.

Independent of age, total and LDL cholesterol concentrations increased with increasing BMI in non-Asian men but neither showed any such trend in the Asian group. In contrast, the decrease in HDL cholesterol and the increase in triglyceride concentrations with increasing BMI was stronger in the Asian group.

These results seem to suggest that there are differences in lipid metabolism between the two ethnic groups, particularly in the metabolism of HDL cholesterol and triglycerides. McKeigue ${ }^{19}$ has linked this and the high prevalence of diabetes found in UK Asian communities to an underlying mechanism of 'insulin resistance' manifest by increased serum insulin concentrations after oral glucose loading in Asian subjects. Our results are therefore consistent with this hypothesis.

These observations have important implications for disease prevention as they suggest that the measurement of total cholesterol concentrations alone may not give an adequate description of 'risk' in Asian men.

The proportion of our non-Asian sample found to have raised blood pressure was high $(23 \%)$ compared with the $12-17 \%$ reported by Mann for British men (using the same criteria to define 'raised'). ${ }^{14}$ Our mean systolic blood pressure value was also higher, whereas the mean diastolic blood pressure value was comparable. Our blood pressure results are therefore also compatible with a higher risk of IHD in non-Asians in Bradford.

The proportion of Asian men with raised blood pressure was slightly higher than that in nonAsians. Other studies have reported either higher blood pressures or a higher prevalence of hypertension in Asians than non-Asians, ${ }^{1617} 19$ and a recent review concluded that mortality from strokes was $53 \%$ higher in Asian men than the national average. ${ }^{4}$ Only a small proportion of those classified as having raised blood pressure were aware of being monitored or treated for this by their own practitioners.

Over $40 \%$ of non-Asian men in Bradford were current smokers; a prevalence comparable with those reported from Glasgow ( $51 \%$ ) and London $(40 \%)$ in Mann's study. ${ }^{14}$ The proportion of smokers did vary with age, however, with the 
youngest age group (less than 30 years) having the lowest proportion. Although proportionally fewer Asian men smoked (almost 50\% had never smoked) and the number of cigarettes smoked per day was lower than in non-Asian men, a level of $39 \%$ currently smoking is still of concern. Furthermore, Asian smoking rates did not vary with age, so anti-smoking education should perhaps be targeted particularly at young Asian men. In our study, smoking rates were higher in Muslims $(46 \cdot 2 \%)$ than Hindus $(22 \cdot 7 \%)$, although in neither sub group were rates as high as the $82 \%$ of Bangladeshis currently smoking reported by McKeigue. ${ }^{16}$ In Miller's study ${ }^{17} 21 \%$ of Indians smoked (comparable with our Hindu group).

Several studies have now reported an independent association between plasma fibrinogen values and cardiovascular disease,${ }^{21-25}$ although the precise relationship between fibrinogen and other predictors such as blood pressure and lipid concentrations remains unclear. Here, plasma fibrinogen values were clearly higher in non-Asians even after correction for the confounding effects of age, BMI, smoking, and occupational status. ${ }^{26}{ }^{28} \mathrm{~A}$ recent study from Sweden ${ }^{28}$ suggested that psychosocial influences are determinants of plasma fibrinogen values; fibrinogen concentration and measures of 'social activity' were inversely associated. In Bradford, Asian societies are close knit and based on the extended family and would provide an excellent basis for further exploration of the Swedish hypothesis.

The role of alcohol consumption in the aetiology of ischaemic heart disease remains controversial. Most would agree, however, that alcohol consumption should be controlled and the Health Education Authority (HEA) guidelines still seem appropriate. ${ }^{29}$ Among the non-Asian drinkers, the mean level of consumption was above the 21 units per week limit advised by the HEA. Alcohol consumption in Asians was less common and more or less restricted to the Hindus (88.6\% were drinkers compared with $3.8 \%$ of Muslims). Among the Asian drinkers, the mean weekly consumption of units was below the HEA advised limit. Both McKeigue ${ }^{16}$ and Miller ${ }^{17}$ also reported lower levels of alcohol consumption in their Asian than non-Asian groups. Alcohol education at present may be more necessary for the non-Asian community but alcohol consumption among Asians, particularly Hindus, should be monitored especially in the younger age groups, who are more likely to adopt western habits.

Whether the effect is direct or indirect, being habitually physically active is likely to protect against heart disease. One study found only vigorous exercise to be of influence, ${ }^{30}$ whereas others have suggested that habitual moderate exercise can be protective. ${ }^{31} 32$ In this Bradford study, all men were employed in similarly active jobs which provided mixed physical activities including walking and moderate and heavy lifting. None of the men, however, confirmed that their work regularly resulted in a 'raised heart rate for 20 or more minutes at a time'. Despite this, many felt that their work provided them with sufficient exercise and were reluctant to participate in exercise outside work. The frequency of exercise taken in leisure time was low in non-Asians and even lower in Asian men. Habitual strenuous exercise has previously been reported to increase HDL cholesterol values. ${ }^{33}$ Promotion of such exercise may therefore be of particular benefit to UK Asian communities.

Although, in statistical terms, obesity does not have an independent effect on ischaemic heart disease risk, ${ }^{1}$ in practical terms it is important as an easily detected factor. An acceptable BMI for adult men lies between 18.0 and $25.0 \mathrm{~kg} / \mathrm{m}^{2} .^{34}$ The mean BMI for non-Asian men in Bradford was over $25.0 \mathrm{~kg} / \mathrm{m}^{2}$, and nearly $50 \%$ from this group and over $40 \%$ of Asian men were classified as overweight or obese. This is high compared with the $32-39 \%$ overweight found in a survey of British adults. ${ }^{35}$

Although less than the desired $100 \%$, the response rate obtained for this study was satisfactory given the high level of involvement and commitment required of participants. The age distribution of the sample obtained was the same as for the sampling frame (total workforce) and similar in both ethnic groups. Although our study was limited to one particular population, the consistency of our data with those of other studies suggests that our findings do not arise from a selection bias but are representative of the true situation.

\section{CONCLUSIONS}

The observed levels of established ischaemic heart disease risk markers in this sample of non-Asian men in Bradford are consistent with the high risk of heart disease historically associated with the Bradford population. Asians resident in Bradford have a very different pattern of risk markers, however, with only their lower HDL cholesterol concentrations, marginally higher triglyceride values, higher prevalence of diabetes, and very low frequency of exercise suggesting an increased risk of ischaemic heart disease compared with nonAsians. McKeigue has made similar observations and has linked the lipid patterns observed in Asians to their higher risk of atherosclerosis and also of diabetes, suggesting an underlying mechanism for both, ${ }^{16}$ an hypothesis supported by our data.

In terms of ischaemic heart disease prevention, our study suggest that it would be inappropriate merely to translate current strategies and advice into Asian languages; different aspects of the preventive message need to be emphasised in strategies targeted at Asian communites. It is now important to extend investigation of risk markers for ischaemic heart disease to younger Asians, women, and other socioeconomic groups.

We are grateful to the staff in the Departments of Biochemistry and Haematology, Bradford Health Authority; the Lipids Clinic, Leeds General Infirmary; and Chemical Pathology, Harrogate General Hospital for their excellent technical assistance. We would also like to thank Dr G Morrison, Jackie McCluney, Andrew Whittles, Sister Valerie Simpson-Cleghorn, and the other nurses for their part in the study; our colleagues for their criticism of the manuscript; Mrs Carol Stainton for statistical advice; the Medical Illustration Department, North Staffordshire Health Authority for the illustrations; and Mrs Janice Joyce for secretarial support. tions; and Mrs Janice Joyce for secretarial support.
Finally, we thank all the staff of both factories who participated in the study, particularly $\mathrm{Mr}$ George Hodgson. 
1 Shaper AG. Coronary heart disease risks and reasons. London: Current Medical Literature, 1988

2 Balarajan R, Bulusu L, Adelstein AM, Shukla V. Patterns of mortality among migrants to England and Wales from the Indian subcontinent. BM7 1984; 289: 1185-7.

3 Marmot MG, Adelstein AM, Bulusu L. Immigrant mortality in England and Wales 1970-78: causes of death by country of birth. London: HMSO, 1984, Office of Population Census and Surve

4 Balarajan R. Ethnic differences in mortality from ischaemic heart disease and cerebrovascular disease in England and Wales. BMF 1991; 302: 560-4.

5 McKeigue PM, Miller GJ, Marmot MG. Coronary heart disease in South Asians overseas: a review. $\mathcal{F}$ Clin Epidemiol 1989; 42: 597-609.

6 Department of Health. Public health common data set. London: HMSO, 1988

7 Kernohan EEM. The health of Bradford. Bradford: Bradford Health Authority Annual Report, 1988

8 Allain CC, Poon LS, Chan CSG, Richmond W, Fu PC. Enzymatic determination of total serum cholesterol. Clin Chem 1974; 20: 470-5.

9 Gidez LI, Miller GJ, Burstein M, Scagle S, Elder HA. Separation and quantitation of subclasses of human plasma
HDL by a simple precipitation procedure. 7 Lipid Res 1982 ; 23: $1206-23$.

10 Friedwald WT, Levy RI, Fredrickson DS. Estimation of serum low density lipoprotein cholesterol without the use of the preparative ultra centrifuge. Clin Chem 1972;18: the preparat

11 Bucolo G, David H. Quantitative determination of serum triglycerides by the use of enzymes. Clin Chem 1973; 19: $476-82$.

12 Shaper AG, Pocock SJ, Walker M, Cohen NM, Wale CJ, Thomson AG. British Regional Heart Study: cardiovascula risk factors in middle-aged men in 24 towns. $B M F 1981$; 283: $179-86$.

13 Study group, European Atherosclerosis Society. Strategies for the prevention of coronary heart disease: a policy statement of the European Atheroschlerosis Society. European Heart $\mathcal{F}$ 1987; 8: 77-88.

14 Mann JI, Lewis B, Shepherd J, et al. Blood lipid concentrations and other cardiovascular risk factors: distribution, prevalence, and detection in Britain. BMf 1988; 296: $1702-6$.

15 McKeigue PM, Marmot MG, Adelstein AM, et al. Diet and risk factors for coronary heart disease in Asians in North West London. Lancet 1985; ii: 1086-90.

16 McKeigue PM, Marmot MG, Court JDS. Cottier DE, Rahman S, Riemersma RA. Diabetes, hyperinsulinaemia, and coronary risk factors in Bangladeshis in East London.

17 Miller GJ, Kotecha S, Wilkinson $\mathrm{WH}_{\mathrm{H}}$ et al. Dietary and other characteristics relevant for coronary heart disease in men of Indian and European descent in London Atherosclerosis 1988; 70: 63-72.

18 Hughes LO, Cruickshank JK, Wright J, Raftery EB. Disturbances of insulin in British Asian and white men surviving myocardial infarction. BMf 1989; 299. $537-41$.

19 McKeigue PM, Shah B, Marmot MG. Relation of central obesity and insulin resistance with high diabetes prevalence obesity and insulin resistance with high diabetes prevalence
and cardiovascular risk in South Asians. Lancet, 1991; 337: 328-6.

20 Lowry PI, Glover DR, Mace PJE, Littler WA. Coronary artery disease in Asians in Birmingham. Br Heart 7 1984; 52 610-13.

21 Wilhelmsen L, Svardsudd K, Korsan-Bengster K, et al. Fibrinogen as a risk factor for stroke and myocardial infarction. New Engl f Med 1984; 311: 501-5.

22 Stone MC, Thorpe JM. Plasma fibrinogen--a major coronary risk factor. F Royal College of Gen Pract 1985; 35: $565-9$.

23 Meade TW, Mellors S, Brozovic M, et al. Haemostatic function and ischaemic heart disease: principle results of the Northwick Park heart study. Lancet 1986; ii: 533-7.

24 Kannel WB, D'Agostino RE, Belanger AJ. Fibrinogen and risk of cardiovascular disease. $7 A M A$ 1987 258: $1183-6$.

25 Qrzilbash N, Jones L, Warlov C, Mann J. Fibrinogen and lipid concentrations as risk factors for transient ischaemic attacks and minor ischaemic strokes. BMF 1991; 303: 605-9.

26 Ernst E. Fibrinogen-an independent cardiovascular risk factor. F Intern Med 1990; 227: 365-72.

27 McKane HLJ, Marmot MG, Shipley MJ, et al. Fibrinogen: a possible link between social class and coronary heart disease. BMF 1985, 291: 1312-4.

28 Rosengren A, Wilhelmsen I, Welin L, et al. Social influences and cardiovascular risk factors as determinants of plasma fibrinogen concentration in a general population sample of middle-aged men. BMF 1990; 300: 634-8.

29 Health Education Authority. That's the limit. A guide to sensible drinking. (Leaflet AL 7) London: HEA. 1985.

30 Chave SPW, Morris JN, Moss S. Vigorous exercise in leisure time and the death rate: a study of male civil servants. 7 Epid Community Health 1978; 32: 239-43.

31 Hardman Ä, Hudson A. Look after your heart (ii). Walking for health--a closer look at exercise. Health Trends 1989; 21: 92-2.

32 Shaper AG, Wannamethee G. Physical activity and ischaemic heart disease in middle-aged British men. $\mathrm{Br}$ Heart f 1991; 66: 384-94.

33 Gordon DJ. Rifkind BM High-density lipoprotein-the clinical implications of recent studies. Neiw Eng F Med 1989; 321: $1311-6$.

34 Thomas B (ed). Manual of dietetic practice, Oxford: Blackwell Scientific Publications, 1988

35 Knight T. The heights and weights of adults in Great Britain. London HMSO, 1984 